\title{
Analysis of Factors Affecting Bank Liquidity
}

\author{
Wei Feng \\ School of Economics, Shanghai University, Shanghai, China \\ Leonwei0124@126.com
}

Keywords: Liquidity, Commercial Bank, Influence Factor.

\begin{abstract}
With the continuous development of Chinese economy, the deepening of the reform of commercial banks, all kinds of commercial banks are also rising. In the face of increasingly fierce competition in the financial market, the liquidity risk management of commercial banks has become an important factor related to the future development of banks. After the financial crisis in 2008, countries have strengthened the control of liquidity risk in the banking sector. This paper focuses on the analysis of the factors that affect the liquidity of commercial banks in China, mainly from two aspects: internal factors and external factors.
\end{abstract}

\section{Introduction}

For a long time, Chinese commercial banks have been lack of awareness and means of risk management. From the beginning of 2003 commercial bank shareholding reform, although the company Chinese commercial bank governance structure and management level has been improved, but the liquidity management methods are still very rough, liquidity risk management is still lack of awareness.

Liquidity risk and credit risk, market risk and operational risk, the reasons for the formation of more complex and extensive, is generally regarded as a comprehensive risk. In addition to the liquidity arrangements, liquidity risk management should also effectively manage other major risks. From this point of view, the liquidity risk level reflects the overall operation of commercial banks.

As a financial intermediary to commercial banks, deposit and loan business based business, bank loans in the draw deposits at the same time, through the loan spreads to gain profits, but the proportion of loans is a difficult problem how to test bank. So, what factors affect the proportion of bank deposits and loans, the bank's liquidity has an impact on it? Through the analysis of the relevant indicators of listed banks, what factors can be drawn?

\section{An analysis of the causes of liquidity risk in bank}

\subsection{Internal Factors}

a) NPL Ratio: The rate of non-performing loans of financial institutions is one of the important indicators to evaluate the security status of financial institutions. Non-performing loan ratio is high, may not be able to recover the proportion of loans to total loans. NPL ratio is low, indicating that financial institutions cannot recover the proportion of loans to total loans smaller. Non-performing loan ratio has a significant impact on commercial banks, is an important basis for judging liquidity.

b) Capital Adequacy Ratio: The capital adequacy ratio reflects the extent to which the bank can take losses on its own capital before the loss of depositors and the assets of creditors. The purpose of this provision is to prevent excessive expansion of risk assets, protect the interests of depositors and other creditors, and ensure the normal operation and development of banks and other financial institutions. The financial authorities of various countries generally have the regulation of the capital adequacy ratio of commercial banks in order to monitor the bank's ability to resist risks. 


\subsection{External Factors}

a) Deposit Reserve: A financial institution's deposits in the central bank for the purpose of ensuring that the customer needs to withdraw deposits and funds. The proportion of the reserve requirement of the central bank to the total deposit is the deposit reserve ratio. By adjusting the deposit reserve ratio, the central bank can affect the ability of credit expansion of financial institutions, and indirectly control the money supply.

b) M2: It is an important indicator to reflect the money supply. M2 rapid growth, investment and intermediate market activity. The central bank and commercial banks may determine monetary policy accordingly. The trend of currency liquidity reflects the loose or tight monetary environment. The change of asset prices in different monetary policy environment is a problem that every institutional investor is concerned with.

\section{Commercial Bank Liquidity index selection}

This paper selects the Loans/Total Deposit (LD for short) as measurement index of liquidity. Chinese CBRC mainly for LD ratio monitoring, LD ratio monitoring index of commercial bank liquidity as Chinese recognized. So there is a scientific basis for LD ratio as liquidity index.

\section{Theoretical Model}

\subsection{Definition and Classification of Panel Data}

Panel data analysis is a new statistical method developed in recent decades. Panel data can overcome the problem of time series analysis, which can provide more information, more changes, less collinearity, more degrees of freedom and higher estimation efficiency and panel data unit root test and cointegration analysis is one of the most cutting-edge field at present.

The panel data is the two-dimensional data obtained in time and section. So, panel data is also called time series and cross section data. Panel data is the repeated observation data of individuals at different points on the cross section.

\subsection{Pooled Model}

If a panel data model is defined as:

$$
Y_{i t}=\alpha+X_{i t}{ }^{\prime} \beta+\varepsilon i t, i=1,2, \ldots, N ; t=1,2, \ldots, T
$$

The Yit is a regression variable (scalar), $\alpha$ Said intercept, Xit is $\mathrm{k} * 1$ order regression variable column vector (including $\mathrm{K}$ regression), $\beta$ is the vector of $\mathrm{k}^{*} 1$ regression system, $\varepsilon$ it is an error term (scalar), This model is called pooled model. The characteristics of the mixed regression model are that the regression coefficients $\alpha$ and $\beta$ are the same for both individuals and sections.

\subsection{Pooled OLS}

The mixed OLS estimation method is to mix n observations on time and cross section, and then estimate the model parameters by OLS method.

Given pooled model:

$$
Y_{i t}=\alpha+X_{i t}{ }^{\prime} \beta+\varepsilon i t, i=1,2, \ldots, N ; t=1,2, \ldots, T
$$

If the model is correct and the explanatory variables are uncorrelated with the error. That is $\operatorname{COV}$ (Xit, $\varepsilon i t)=0$. Whether the $\mathrm{N}$ tends to infinity or the $\mathrm{T}$ tends to infinity. The OLS estimators of the model parameters are consistent. 


\section{Empirical Research}

\subsection{Sample Selection}

This paper studies the long-term liquidity problem of commercial banks, and makes a comprehensive evaluation of the liquidity of the major commercial banks in the first half of 2007 in the year of 2015.

This paper selects the bank: Bank of Chin, Agricultural Bank of China, Industrial \& Commercial Bank of China, Communicate Bank of china, China Construction Bank, China Pudong Development Bank, Industrial and Commercial Bank, Minsheng Bank, China Everbright Bank, China Merchants Bank. 2007-2015 quarterly data as sample data, data from Wind database.

\subsection{Variable Declaration}

This paper focuses on the analysis of the influence of internal factors on the liquidity of commercial banks. Therefore, the choice of non-performing loan ratio and capital adequacy ratio as explanatory variables.

Through the liquidity risk theory and management methods, non-performing loan ratio and capital adequacy ratio play a key role in the liquidity of commercial banks. The non-performing loan ratio and the capital adequacy ratio directly determine the credit investment decision. The actual size of the impact of the NPL ratio and the capital adequacy ratio on the mobility of the capital adequacy ratio is studied through the econometric model.

\subsection{Model Building}

Model formula:

$$
\text { LDit }=\alpha+\beta 1 N P L i t+\beta 2 C M P i t+\text { git }
$$

$\alpha$ is constant, $\beta 1, \beta 2$ are estimated coefficient.

\subsection{Empirical Results and Analysis}

a) unit root test

The unit root test of CMP and NPL was carried out. As you can see from the following table, there is no unit root

Table 1 Stationarity Test

\begin{tabular}{|c|c|c|c|}
\hline Test method & CMP & NPL & unit root \\
\hline ADF - Fisher Chi-square & $(50.17)^{* *}$ & $(36.22)^{*}$ & No \\
\hline PP - Fisher Chi-square & $(51.32)^{* *}$ & $(42.45)^{* *}$ & No \\
\hline
\end{tabular}

b) parameter estimation

Secondly, Using a pooled panel model using pooled OLS to estimate parameters and constants. The statistical results are as follows:

Table 2 Panel Data Regression Statistics

\begin{tabular}{|c|c|c|c|c|}
\hline Variable & Coefficient & Std. Error & t-Statistic & Prob. \\
\hline C & 78.53736 & 2.796622 & 28.08293 & 0 \\
\hline CMP? & -0.737211 & 0.230683 & -3.19578 & 0.0016 \\
\hline LOG(NPL?) & -5.767269 & 0.73716 & -1.823629 & 0.0036 \\
\hline
\end{tabular}

Through EVIES8.0 calculation model, the results are as follow:

$$
\text { LDit=78.5-5.7log(NPLit)-0.73CMPit+ git }
$$




\section{Conclusion}

Through the analysis of the model, can draw the non-performing loan ratio and the capital adequacy ratio has a significant effect on LD ratio. The NPL ratio to LD ratio is negatively correlated, when commercial banks non-performing loan ratio increased, the LD ratio will decline. Due to the increase in non-performing loans, commercial banks are unwilling to take on greater credit risk, so reduce the issuance of loans. Reduce loans directly lead to LD ratio decreased, consistent calculation results of the model and the actual situation of the commercial bank.

The CMP ratio to LD ratio is negatively correlated, when commercial banks capital adequacy ratio increased, the LD ratio will decline. The loose degree of commercial banks' own capital directly affects the liquidity of commercial banks. Usually commercial banks own capital adequacy bank liquidity is more abundant, the lower the liquidity of their own banks are more tense. The minimum requirement of capital adequacy ratio of commercial banks of the New Basel Agreement to the role of escort for the liquidity risk of commercial banks.

\section{Acknowledgements}

This paper is completed under the guidance of professor Gui, so that I can very well grasp and apply the professional knowledge, and embodied in this paper. It is with his help and support, to make my graduation thesis work successfully completed, in this to the Financial College, Shanghai University.

\section{References}

[1] Steven L.Schwarcz. The Alchemy of Asset Securitization [J]. Business and Finance, 1994(4).

[2] Emmanuel Farhi and Jean Tirole. Collective Moral Hazard. Maturity Mismathand Systemic Bailouts [J]. working paper,2009(8).

[3] Eric Wong, Cho-Hoi Hui,A Liquidity Risk Stress-Testing Framework with Interaction between Market and Credit Risks, Hong Kong Monetary Authority, Working Papers, 2009.

[4] Malevergne,Y, Somette,D. Testing the Gaussian copula hypothesis for financial assets dependences [J]. Quantitative Finance, 2003, 3: 23 1-250.

[5] Embrechts, E, Hoing, A. ,Juri, A. Using Copulas to Bound the Value-at-Risk for Functions of Dependent Risks [J]. Finance and Stochastics, 2003, 7(2): 145-1 66.

[6] Rajna Gibson, Nicolas Mougeot. The pricing of systematic liquidity risk: Empirical evidence from the US stock market [J], Journal of Banking and Finance, 2004, 28(1): 157—178. 